Reprinted with permission from: Weed Technology. 1996. 10(2):392-403.

Published and copyrighted by: Weed Science Society of America. http://www.wssa.net

\title{
Imidazolinone herbicides improve restoration of Great Plains grasslands ${ }^{1}$
}

\author{
ROBERT A. MASTERS, SCOTT J. NISSEN, ROCH E. GAUSSOIN, DANIEL D. \\ BERAN, and ROBERT N. STOUGAARD
}

Rangeland Sci., U.S. Dep. Agric., Agric. Res. Serv:, Asst. Prof.. Dep. Agron., Univ. Nebraska, Lincoln, NE 68583, Asst. Prof, Dep. Hortic.. Univ. Nebraska, Lincoln. NE 68583, Res. Asst.. and Asst. Prof. Dep. Agron., Univ. Nebraska. Lincoln, NE 68583. Current address of S. J. Nissen: Dep. Plant Pathol. Weed Sci.. Colorado State Univ., Ft. Collins 80523 and R. N. Stougaard: Northwest. Agric. Res. Cent.. Kalispell, MT 59901.

\begin{abstract}
:
The productivity and native species diversity of Great Plains grasslands have been substantially reduced by past management that facilitated the establishment of invasive exotic weeds and displacement of native species. Management strategies are needed to rapidly restore the productive capacity and biological diversity of these degraded grasslands. Critically important phases of the grassland restoration process are the reintroduction and establishment of native species. Weed interference is the primary constraint to successful establishment of native plants. The goal of our research is to develop strategies that use multiple technologies, including herbicides, to expedite grassland revegetation with native grasses and forbs. Imidazolinone herbicides (AC 263,333, imazapyr, and imazethapyr) were used successfully to improve establishment of native perennial grasses (big bluestem, switchgrass, little bluestem) and selected forbs (blackeyed-susan, purple prairieclover, Illinois bundleflower, trailing crownvetch, and upright prairie coneflower) on cropland and as components of a strategy to revegetate leafy spurge-infested rangeland with native tallgrasses. Imazethapyr at 70 or $110 \mathrm{~g}$ ai/ha applied at planting resulted in stands of big bluestem and little bluestem that were similar or superior to stands established where atrazine was applied. Seedling grasses were susceptible to imazapyr at two of three study sites. Imazapyr at $560 \mathrm{~g}$ ai/ha plus sulfometuron at $100 \mathrm{~g}$ ai/ha applied in fall was the optimum treatment for suppression of leafy spurge and exotic cool-season grasses and establishment of big bluestem and switchgrass on degraded rangeland sites. Establishment of selected forbs was improved by PRE treatment with AC 263,222 or imazethapyr at $70 \mathrm{~g}$ ai/ha. This research provides evi-
\end{abstract}

\footnotetext{
${ }^{1}$ Received for publication May 31995 and in revised form Dec. 15. 1995. Contr. no. 11129, Agric. Res. Div., Univ. Nebraska. Lincoln, and the U.S. Dep. Agric., Agric. Res. Serv.
} 
dence that the imidazolinone herbicides can be important components of integrated weed management strategies designed to reverse deterioration of grasslands by reestablishing native species, improving grassland productivity, and decreasing the prevalence of exotic weeds.

\section{Nomenclature:}

Atrazine, 6-chloro- $N$-ethyl- $N{ }^{\prime}$-(1-methylethyl)-1,3,5-triazine-2,4-diamine; imazapyr, ( \pm )-2- [4,5-dihydro-4-methyl-4- (1-methylethyl) -5-oxo- $1 \mathrm{H}$-imidazol-2-yl]-3-pyridinecarboxylic acid; AC 263,222, ( \pm )-2-[4,5-dihydro-4methyl-4-(1-methylethyl)-5-oxo-1H-imidazol-2-yl]-5-methy1-3-pyridinecarboxylic acid; imazethapyr, 2-[4,5-dihydro-4-methyl-4-(1-methylethyl) -5-oxo-1 $H$-imidazol-2-yl]1-5-ethyl -3 -pyridinecarboxylic acid; sulfometuron, 2-[[[[(4,6-dimethyl-2-pyrimidinyl) amino] carbonyl] amino] sulfonyl] benzoic acid; leafy spurge, Euphorbia esula L. $\#^{2}$ EPHES; big bluestem, Andropogon gerardii Vitman 'Pawnee' \# ANOGE; little bluestem, Andropogon scoparium (Michx.) Nash 'Camper' \# ANOSC; switchgrass, Panicum virgatum L. 'Trailblazer,'\# PANI; blackeyed-susan, Rudbeckia hirta L. var. hirta \# RUDHI; purple prairieclover, Dalea purpurea Vent.; Illinois bundleflower, Desmanthus illinoensis (Michx.) MacMill. ex B.L. Robins \# DEMIL; trailing crownvetch, Coronilla varia L. \# CZRYA; upright prairie coneflower, Ratibida columnifera (Nutt.) Woot. \& Stand]. \# RATCO.

\section{Additional index words:}

Biological diversity, cool-season grasses, forbs, AC 263,222, glyphosate, imazapyr, imazethapyr, leafy spurge, native plants, prairie restoration, rangeland, sulfometuron, tall-grasses, warm-season grasses, wildflowers, ANOGE, ANOSC, CZRYA, DEMIL, EPHES, PANI, RATCO, RUDHI.

\section{Introduction}

Grasslands of the Great Plains, once among the most extensive and floristically rich communities in North America, are now among the most reduced (6). The primary reasons for degradation of these grasslands include conversion to cropland or improper grazing by domestic livestock. Less than 3\% of the original 100 million ha of the tallgrass prairie remains in the Great Plains (17). More than 11.6 million ha of tallgrass prairie in Iowa were converted to cropland between 1825 and 1920 (17). In Nebraska, about 40\%

\footnotetext{
${ }^{2}$.Letters following this symbol are a WSSA-approved computer code from Composite List of Weeds, Revised 1989. Available from WSSA, 1508 West University Ave., Champaign. IL 61821-3133.
} 
or 7.7 million ha of mixed-grass and tallgrass prairies has been converted to cropland (20).

In many areas of the central and northern Great Plains, the deep rich soils that developed under grasslands are ideally suited for crop production. However, large areas of grasslands that are not well suited to crop production also have been converted to cropland. In Iowa, Minnesota, Missouri, Nebraska, and North and South Dakota, more than 7.6 million ha of cropland are in capability classes IV through VIII (20). Crop production on land in these capability classes is often marginally economical and increases natural resource degradation. Land in these classes is usually better suited to production of perennial forages than annual crops.

Grasslands that have not been converted to cropland are usually fragmented, degraded communities with reduced native species diversity and are producing at about $30 \%$ of their potential (8). Weaver and Fitzpatrick (22) indicated that loss of species diversity in intact grasslands resulted from intensified grazing by domestic livestock. Improper grazing caused a shift in species composition from palatable native perennials to less palatable species and reduced the amount of plant residue available to carry a fire. Exclusion of fire disrupted the natural fire regimes that were essential to the formation and maintenance of Great Plains grasslands. Increased grazing pressure combined with reduced fire frequency altered competitive interactions among grassland species. This has created gaps available for occupation by exotic species and less palatable native species. As a result, many grasslands are either in a retrogressive succession mode, characterized by a continued decline in native species diversity, primary and secondary productivity, plant cover, and soil quality $(1,2)$, or at a steady state condition producing far below their potential.

Deterioration of many grasslands has occurred for a sufficient time to cause local extinction of palatable native species and increased prevalence of weedy exotic species. Some exotic species, Kentucky bluegrass (Poa pratensis L.) and smooth bromegrass (Bromus inermis Leyss.), can be grazed by livestock. Many exotic species including leafy spurge, musk thistle (Carduus nutans L.), Canada thistle [Cirsium arvense (L.) Scop.], and spotted knapweed (Centaurea maculosa Lam.), are unpalatable and not utilized by cattle. These invasive exotic species have substantially altered the function and structure of grassland ecosystems.

One goal of grassland weed management is to increase forage production by controlling brush and herbaceous weeds (4). Herbicides are important tools that are used frequently to meet this goal. The outcome of using some herbicides has been to reduce further the biological diversity of degraded grasslands by selectively removing or suppressing native forbs and perpetuating the dominance of tenacious exotic species. Long-term use of 2,4-D (2,4-dichlorophenoxy) acetic acid], dicamba (3,6-dichloro-2methoxy-benzoic acid), and picloram (4-amino-3,5,6-trichloro-2-pyridinecarboxylic acid) to control leafy spurge and musk thistle on rangelands in Nebraska contributed to reducing native forb populations $(10,11)$.

The combined forces of overgrazing, exclusion of fire, and application of broadleafspecific herbicides accelerated the conversion of native grasslands from complex communities with a rich assortment of grasses and forbs to more simplistic less diverse com- 
munities dominated by a few exotic species and early successional native species. These simplified communities persist as this suite of selection forces continues to be applied.

Grassland ecosystems have the potential to provide high quality forage for livestock, habitat for wildlife, water, and recreation, and to serve as a repository for diverse native plant germplasm. To realize this potential, strategies are needed to establish diverse mixtures of native grasses and forbs rapidly over large areas of degraded grasslands and marginal cropland. Current guidelines for grassland revegetation are usually anecdotal, based on experiences of practitioners $(3,12,14,16)$. These practitioners consistently indicate that weed interference is the primary obstacle to efficient and effective grassland restoration.

Management systems that integrate herbicides, fire, and planting competitive native species have the potential to reduce weed interference and increase grassland biological diversity and carrying capacity. Herbicides are an essential component of management strategies that are being developed to establish native grasses and forbs in Great Plains grasslands. The imidazolinone herbicides are particularly promising because several native grasses and forbs are tolerant to members of this herbicide family. We will present findings from three studies designed to evaluate the use of imidazolinone herbicides: (a) to improve establishment of native perennial grasses on cropland; (b) as components of a strategy to reclaim leafy spurge-infested rangeland; and (c) to improve establishment of selected forbs. These studies are part of a program to develop weed management strategies that will contribute to restoration of Great Plains grasslands by increasing native species diversity, improving carrying capacity, reversing natural resource degradation, and decreasing invasive exotic species.

\section{Materials and methods}

\section{Grass establishment on cropland}

Experiments were conducted at the University of Nebraska Agricultural Research and Development Center near Mead, NE, and South Central Research and Extension Center near Clay Center, NE from 1991 through 1993. The soil at Mead was a Sharpsburg silty clay loam (fine, montmorillonitic, mesic, Typic Argiudoll) and at Clay Center was a Hastings silt loam (fine, montmorillonitic, mesic Udic Argiustolls).

Cropping history varied at the research sites. At Mead, soybean [Glycine max (L.) Merr.] was grown for two to three consecutive years before experiments were initiated. Velvetleaf (Abutilon theophrasti Medicus \# ABUTH) and redroot pigweed (Amaranthus retroflexus L. \# AMARE) were common at sites planted at Mead in 1991 and 1992. Green foxtail [Setaria viridis (L.) Beauv. \# SETVI], yellow foxtall [Setaria glauca (L.) Beauv. \# SETLU], and fall panicum (Panicum dichlotomiflorum Michx. \# PANDI) stands were greatest on the site planted in 1991. At Clay Center, the research site was followed with no herbicide treatment for one year before the experiment was initiated. Before the fallow period, sorghum [Sorghum bicolor (L.) Moench] was grown for three consecutive years, Fall panicum, green and yellow foxtails, and stinkgrass [Eragrostis cilianensis (All.) E. Mosher \# ERACN] were the dominant grass weeds. Pennsylvania 
smartweed (Polygonum pensylvanicum L. \# POLPY), redroot pigweed, and common sunflower (Heliatithus annuus L. \# HELAN) were the most common broadleaf weeds.

Experiments were designed as randomized complete blocks with four replications of each herbicide treatment. Treatments were arranged in a split plot design with herbicide treatment as the main plot factor and grass species as the sub-plot factor. Atrazine at 2200 $\mathrm{g}$ ai/ha and imazapyr and imazethapyr, each at 45, 70, and $110 \mathrm{~g} / \mathrm{ha}$, were applied PRE within 5 days after grasses were planted and before weeds or seeded grasses emerged. Imazethapyr also was applied POST to previously non-treated plots at 45, 70, and 110 $\mathrm{g} /$ ha after the planted grasses reached the 4-to 6-leaf growth stage. Herbicides were applied with a tractor-mounted, compressed air-pressurized sprayer at $280 \mathrm{kPa}$ to achieve a delivery of $190 \mathrm{~L} / \mathrm{ha}$. A nonionic surfactant $\mathrm{t}^{3}$ at $0.25 \% \mathrm{v} / \mathrm{v}$ was included in the spray solution for POST applications.

'Pawnee' big bluestem, 'Camper' little bluestem, and 'Trailblazer' switchgrass were planted at 660 pure live seeds (PLS) ${ }^{5} / \mathrm{m}^{2}$ using a seven-row plot drill with an $18-\mathrm{cm}$ spacing between rows. Grasses were planted in separate 1.6- by $8-\mathrm{m}$ subplots within 5- by 8m main plots at Mead on 9 May, 1991 and 20 May, 1992 and at Clay Center on 26 May, 1992. Grass seed were planted to a 1.2-cm depth in seedbeds that had been disked, harrowed, and cultipacked about 21 days before planting.

Study sites were burned in late April of the year after planting to remove plant residue, A mixture of $1100 \mathrm{~g} / \mathrm{ha}$ of 2,4-D low volatile ester and $2200 \mathrm{~g} / \mathrm{ha}$ each of atrazine and metolachlor [2-chloro- $N$-(2-ethyl-6-methylphenyl) $-N-(2-$ methoxy-1-methylethyl) acetamide] was applied in a spray volume of $190 \mathrm{~L} /$ ha to the study sites about 14 days after burning. Fire and herbicide treatments were applied to reduce weed interference with sampling the year after planting. Established ( $\geq 1$-year-old) stands of certain perennial warm-season grasses have been determined to be tolerant to the mixture of herbicides applied (9).

Grass establishment was determined by measuring stand frequency of occurrence and herbage mass about 15 months after herbicide treatment (MAT) ${ }^{4}$. Measurements taken the year after planting provided estimates of forage production potential of the perennial native grasses. Frequency was measured because it integrates pattern and abundance (5), two important attributes when determining grass establishment. Frequency measurements were determined using a 75 - by $75-\mathrm{cm}\left(0.56 \mathrm{~m}^{2}\right)$ metal frame partitioned into a grid of 25 squares, $15 \mathrm{~cm}$ on a side (21). The frame was placed over the center five rows at two locations within each subplot and number of squares within the frame containing at least one seeded grass was recorded. Stand frequency within each frame was calculated by dividing the number of squares that contained at least one seeded grass plant by 25 and then multiplying by 100 to convert the calculated proportion to a percentage.

Herbage mass was determined by cutting the herbage in the center five rows for a length of $4 \mathrm{~m}$ in each plot to a $10-\mathrm{cm}$ stubble height after the grass cultivars had reached

\footnotetext{
${ }^{3}$ X -77, Valent U.S.A. Corp., 1333 N. California Blvd., Walnut Creek, CA 94596.

${ }^{4}$ Abbreviations: MAT, months after herbicide treatment; n. sample size; PLS. pure live seeds: SE. standard error of the mean.
}

Page 5 of 18 
heading. Wet weight of herbage from each plot was adjusted to dry matter weight by drying a 500 -g subsample at $60 \mathrm{C}$ for 48 hours to determine dry matter content.

Error variances associated with experiments conducted at each site were determined to be heterogeneous according to Bartlett's test (13); therefore, data from each site were analyzed separately. Mean grass stand frequency and herbage mass estimates were compared using Fisher's-protected LSD $(\mathrm{P}<0.05)$.

\section{Leafy spurge-infested rangeland reclamation}

Experiments were initiated in 1992 at sites near Ainsworth and Ansley, NE. The Ainsworth site was a sub-irrigated meadow that was hayed annually in mid-July for several years before this study was conducted. Sub-irrigated meadows are common in the Sand Hills rangeland of Nebraska and are a valuable forage resource. The seasonal high water table on sub-irrigated meadows fluctuates on average from $15 \mathrm{~cm}$ above the soil surface during wet years to $75 \mathrm{~cm}$ below the soil surface in dry years (7). The Ansley site was a mixed-grass prairie with a management history of moderate to heavy continuous grazing by cattle during the spring and summer. The soil at Ainsworth was a Tryon loamy fine sand (mixed, mesic, Typic Psammaquent) and at Ansley was an Uly silt loam (mixed, mesic, Typic Haplustoll).

Kentucky bluegrass was the dominant cool-season grass and smooth bromegrass was common at both sites. Warm-season grasses that were present, but not common, at Ansley were tall dropseed [Sporobolus asper (Michx.) Kunth]. sand dropseed [Sporobolus cryptandrus (Torr.) A. Gray \# SPZCRI, blue grama [Bouteloua gracilis (H.B.K.) Lag. ex Steud.], and buffalograss [Buchloe dactyloides (Nutt.) Engelm. \# BUCDA], and at Ainsworth were big bluestem. switchgrass, and little bluestem. Leafy spurge stands were relatively uniform at both sites with an average density of $128 \mathrm{stems} / \mathrm{m}^{2}$ [standard error (SE) ${ }^{5}$ $=5$, sample size $\left.(n)^{5}=50\right)$ at Ainsworth and $141 \mathrm{stems} / \mathrm{m}^{2}\left(\mathrm{SE}=9,{ }^{\circ} n=52\right)$ at Ansley. Sites were not grazed or hayed for the duration of the study.

Experiments at both sites were designed as randomized complete blocks arranged as a split plot with four replications of each treatment combination. Herbicide treatment was the main plot effect and planted grass species were the subplot effect. Sulfometuron at $100 \mathrm{~g}$ ai/ha, imazapyr at 280,560 , or $840 \mathrm{~g} / \mathrm{ha}$, and glyphosate [ $N$-(phosphono-methyl) glycinel at $630 \mathrm{~g}$ ae/ha were applied on 30 Sept., 1992 at Ansley and 1 Oct., 1992 at Ainsworth. Imazapyr and sulfometuron were applied alone or in combination at the rates indicated.

Leafy spurge shoots were at the vegetative to post-flowering phenological stage of development when treated, and plant height was between 50 and $70 \mathrm{~cm}$. Herbicides were applied with a tractor-mounted, compressed air-pressurized sprayer traveling at $3 \mathrm{~km} / \mathrm{h}$. A nonionic surfactant ${ }^{3}$ at $0.25 \% \mathrm{v} / \mathrm{v}$ was included in the spray solution. The sprayer delivered $190 \mathrm{~L} / \mathrm{ha}$ at $280 \mathrm{kPa}$ to 5 - by 8 -m plots.

Research plots were burned with a headfire on 21 Apr., 1993 at Ansley and 22 Apr., 1993 at Ainsworth to remove plant residue in preparation for planting. 'Pawnee' big bluestem, 'Holt' indiangrass [Sorghastrum nutans (L.) Nash ex Small], and 'Trailblazer' switchgrass were planted at $440 \mathrm{PLS} / \mathrm{m}^{2}$ using a seven-row plot drill with an $18-\mathrm{cm}$ spac-

Page 6 of 18 
ing between rows. Grass cultivars were planted in separate 1.6- by 8-m subplots within 5by $8-\mathrm{m}$ main plots. Grass seeds were planted at a 1.2-cm depth directly into the sod with no tillage on 3 May, 1993 at both sites.

Stand frequency of the planted grasses and herbage mass of selected components of the vegetation were measured in early August 1993 to assess the response of plant communities to treatments. Stand frequency was determined as previously mentioned. Vegetation was harvested within two $0.25-\mathrm{m}^{2}$ quadrats located within each subplot. Vegetation within each quadrat was clipped to a 2-cm stubble height, separated into selected categories, ovendried at $60 \mathrm{C}$, and weighed. Vegetation was separated into the following categories: big bluestem, switchgrass, or indiangrass; leafy spurge; warm-season grasses (not including planted grasses); cool-season grasses; and forbs.

Data from Ainsworth and Ansley study sites were analyzed separately because error variances were heterogeneous according to Bartlett's test (13). Mean stand frequency of the planted grasses and herbage mass estimates were compared using Fisher's-protected LSD $(\mathrm{P} \leq 0.05)$.

\section{Forb establishment}

Experiments were conducted on irrigated and non-irrigated sites at the John Seaton Anderson Turfgrass Research Facility near Mead, NE. Before this study, the sites were maintained in tall fescue (Festuca arundinacea Schreb. \# FESAR) sod. Soil at both sites was a Sharpsburg silty clay loam. The irrigated site received a minimum of $2.5 \mathrm{~cm}$ of water each week by sprinkler irrigation and/or rainfall. The non-irrigated site received water only during precipitation events.

Experiments at both sites were designed as randomized complete blocks with four replications. Sites were tilled and cultipacked in preparation for planting. A $60-\mathrm{cm}$ border of Kentucky bluegrass sod was planted around four rows of 18 plots. Each plot was 0.9 by $1.8 \mathrm{~m}$. Within each plot, a single species was seeded at a depth of $1.2 \mathrm{~cm}$ into three rows that were $20 \mathrm{~cm}$ apart. Blackeyed-susan at $810 \mathrm{PLS} / \mathrm{m}^{2}$, Illinois bundleflower at 260 $\mathrm{PLS} / \mathrm{m}^{2}$, purple prairieclover at $580 \mathrm{PLS} / \mathrm{m}^{2}$, trailing crownvetch at $285 \mathrm{PLS} / \mathrm{m}^{2}$, and upright prairie coneflower at $270 \mathrm{PLS} / \mathrm{m}^{2}$ were planted on 8 June, 1994. All species, except trailing crownvetch, are native to North America.

Herbicides were applied to individual plots on 10 June, 1994. The herbicide treatments were no herbicide and imazethapyr or AC 263,222 applied at $70 \mathrm{~g} / \mathrm{ha}$. Crop oil concentrate $^{5}$ at $1.25 \% \mathrm{v} / \mathrm{v}$ and $28 \%$ urea ammonium nitrate at $1.25 \% \mathrm{v} / \mathrm{v}$ were added to the spray solution. Herbicides were applied with a $\mathrm{CO}_{2}$-pressurized back-pack sprayer that delivered $163 \mathrm{~m}^{1} / \mathrm{m}^{2}$ at $240 \mathrm{kPa}$.

Visual estimates of weed control and seedling emergence were measured I MAT and foliar cover was measured at 2.5 MAT. The variables were expressed as a percentage on a scale of 0 to $100 \%$ where $0 \%$ represented no response and $100 \%$ represented complete weed control, seedling emergence, and canopy closure. Arcsine transformed and nontransformed data were analyzed using general linear model procedures (18). Non-

\footnotetext{
${ }^{5}$ SUN-IT II, Agsco, Inc., Grand Forks. ND 58206-0458.
} 
transformed data are presented because results between analysis of transformed and nontransformed data were similar. Variables were compared using Fisher's-protected LSD (P $\leq 0.05)$.

\section{Results and discussion}

\section{Grass establishment on cropland}

Response of the native grasses to herbicide treatments varied by site. At Mead in 1992, imazethapyr at $70 \mathrm{~g} / \mathrm{ha}$ PRE consistently resulted in greater stand frequency and herbage mass of each grass species compared to grasses that were not treated with herbicide during the year of planting (Table 1). Compared to non-treated plots, imazethapyr at $70 \mathrm{~g} / \mathrm{ha}$ increased herbage mass of big bluestem by $4110 \mathrm{~kg} / \mathrm{ha}$, little bluestem by 3120 $\mathrm{kg} / \mathrm{ha}$, and switchgrass by $6740 \mathrm{~kg} / \mathrm{ha}$. Stand frequencies or herbage mass of big bluestem or switchgrass treated with imazethapyr PRE at $70 \mathrm{~g} /$ ha were no different than that of tallgrasses treated with atrazine. In contrast, little bluestem herbage mass was greater where imazethapyr was applied PRE at 70 or $110 \mathrm{~g}$ ha than in plots treated with atrazine.

Table 1. Stand frequency and herbage mass of big bluestem (BB), little bluestem (LB), and switchgrass (SW) determined in August 1992, 15 months after planting, near Mead, NE in May 1991.

\begin{tabular}{|c|c|c|c|c|c|c|c|c|}
\hline \multirow[t]{2}{*}{ Herbicide } & \multirow[t]{2}{*}{ Rate } & \multirow[t]{2}{*}{$\begin{array}{c}\text { Time of } \\
\text { Application }^{\mathrm{a}}\end{array}$} & \multicolumn{3}{|c|}{ Stand frequency } & \multicolumn{3}{|c|}{ Herbage mass } \\
\hline & & & $\mathrm{BB}$ & LB & SW & BB & LB & SW \\
\hline & $\mathrm{g}$ ai/ha & & & $-\%$ & & 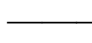 & $\mathrm{kg} / \mathrm{ha}$ & \\
\hline Non-treated & 0 & & 55 & 11 & 38 & 1950 & 170 & 2250 \\
\hline Atrazine & 2200 & PRE & 95 & 39 & 84 & 6650 & 1800 & 10920 \\
\hline Imazapyr & 45 & PRE & 71 & 48 & 79 & 4840 & 1900 & 9020 \\
\hline Imazapyr & 70 & PRE & 51 & 28 & 52 & 4810 & 1700 & 7530 \\
\hline Imazapyr & 110 & PRE & 26 & 15 & 36 & 4120 & 1180 & 7070 \\
\hline Imazethapyr & 45 & PRE & 93 & 26 & 72 & 5480 & 1130 & 7540 \\
\hline Imazethapyr & 70 & PRE & 97 & 62 & 87 & 6060 & 3290 & 8990 \\
\hline Imazethapyr & 110 & PRE & 94 & 58 & 68 & 6160 & 4430 & 7710 \\
\hline Imazethapyr & 45 & POST & 93 & 18 & 81 & 4250 & 700 & 5870 \\
\hline Imazethapyr & 70 & POST & 87 & 6 & 61 & 3520 & 500 & 3990 \\
\hline Imazethapyr & 110 & POST & 83 & 15 & 78 & 3490 & 260 & 6700 \\
\hline $\operatorname{LSD}(0.05)$ & & & 22 & 28 & 31 & 1770 & 1380 & 3070 \\
\hline
\end{tabular}

Native grass stand frequencies declined as rate of imazapyr increased from 45 to 110 $\mathrm{g} /$ ha (Table 1). Stand frequencies of the native grasses treated with imazapyr at $70 \mathrm{ga} / \mathrm{ha}$ were similar to grasses not treated with herbicide, but less than grasses treated PRE with imazethapyr at $70 \mathrm{~g} / \mathrm{ha}$. In contrast, there was no difference in herbage mass of big bluestem or switchgrass treated with imazapyr or imazethapyr PRE at $70 \mathrm{~g} / \mathrm{ha}$. Little bluestem 
herbage mass was less where imazapyr at $70 \mathrm{~g} / \mathrm{ha}$ or atrazine was applied compared to PRE treatment with imazethapyr at $70 \mathrm{~g} / \mathrm{ha}$.

Imazethapyr treatments applied POST usually were not as effective as PRE applications for improving establishment of the native grasses. Imazethapyr at $70 \mathrm{~g} / \mathrm{ha}$ PRE resulted in greater big bluestem and switchgrass herbage mass than did imazethapyr applied POST (Table 1). Little bluestem stand frequencies and herbage mass were greater where imazethapyr at 70 or $110 \mathrm{~g} / \mathrm{ha}$ were applied PRE rather than POST. Efficacy of POST treatments of imazethapyr was reduced because applications were delayed by excessive rainfall, which left the soil too wet to use spray equipment. Weeds were too mature for optimum control by the time POST treatments were applied in late June 1991.

At Mead in 1993, switchgrass stand frequencies were reduced to $44 \%$ or less after treatment with imazethapyr at 70 or $110 \mathrm{~g} / \mathrm{ha}$, applied PRE or POST, or imazapyr at all rates (Table 2). Big bluestem stand frequencies were decreased by imazapyr at 70 or 110 $\mathrm{g} /$ ha compared to stands in plots treated with imazethapyr or atrazine. Imazethapyr and imazapyr at 45 or $70 \mathrm{~g} /$ ha increased little bluestem stand frequencies compared to stands in atrazine-treated plots. There were no differences in the herbage mass of big bluestem or switchgrass treated with atrazine or imazethapyr PRE or POST. Little bluestem herbage mass from plots treated with atrazine or not treated with herbicide was at least $40 \%$ less than herbage mass from plots treated with the imidazolinone herbicides, except imazethapyr POST at $45 \mathrm{~g} / \mathrm{ha}$.

Table 2. Stand frequency and herbage mass of big bluestem (BB), little bluestem (LB), and switchgrass (SW) determined in August 1993, 15 months after planting, near Mead, NE in May 1992.

\begin{tabular}{|c|c|c|c|c|c|c|c|c|}
\hline \multirow[b]{2}{*}{ Herbicide } & \multirow[b]{2}{*}{ Rate } & \multirow[b]{2}{*}{$\begin{array}{c}\text { Time of } \\
\text { Application }^{\mathrm{a}}\end{array}$} & \multicolumn{3}{|c|}{ Stand frequency } & \multicolumn{3}{|c|}{ Herbage mass } \\
\hline & & & $\mathrm{BB}$ & LB & SW & $\mathrm{BB}$ & LB & SW \\
\hline & $\mathrm{g}$ ai/ha & & 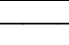 & $\%$ & 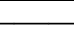 & 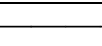 & $-\mathrm{kg} / \mathrm{h}$ & 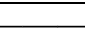 \\
\hline Non-treated & 0 & - & 83 & 55 & 59 & 6890 & 3030 & 6560 \\
\hline Atrazine & 2200 & PRE & 80 & 34 & 71 & 7110 & 3290 & 8730 \\
\hline Imazapyr & 45 & PRE & 77 & 63 & 37 & 7900 & 5850 & 6960 \\
\hline Imazapyr & 70 & PRE & 52 & 56 & 21 & 8940 & 5870 & 5940 \\
\hline Imazapyr & 110 & PRE & 33 & 45 & 10 & 8130 & 7110 & 4500 \\
\hline Imazethapyr & 45 & PRE & 90 & 80 & 45 & 7120 & 6940 & 6870 \\
\hline Imazethapyr & 70 & PRE & 81 & 81 & 40 & 8090 & 8350 & 6610 \\
\hline Imazethapyr & 110 & PRE & 77 & 74 & 26 & 8390 & 9920 & 5470 \\
\hline Imazethapyr & 45 & POST & 72 & 23 & 54 & 5350 & 1360 & 6290 \\
\hline Imazethapyr & 70 & POST & 79 & 67 & 44 & 7670 & 5630 & 6190 \\
\hline Imazethapyr & 110 & POST & 82 & 76 & 28 & 8160 & 6650 & 6040 \\
\hline LSD (0.05) & & & 17 & 23 & 23 & 1800 & 2280 & NS \\
\hline
\end{tabular}

At Clay Center in 1993, herbage mass of the native grasses was greater in plots where imazethapyr and imazapyr were applied PRE at 70 or $110 \mathrm{~g} / \mathrm{ha}$ compared to non-treated plots (Table 3). Grass stand frequencies and herbage mass were low where atrazine was 
applied and were the same as that in non-treated plots. Stand frequencies and herbage mass of big bluestem and little bluestem were greater where imazethapyr or imazapyr were applied at 70 or $110 \mathrm{~g} / \mathrm{ha}$ than where atrazine or no herbicide was applied. Switchgrass herbage mass was greatest where imazapyr was applied PRE at 70 or $110 \mathrm{~g} / \mathrm{ha}$.

Table 3. Stand frequency and herbage mass of big bluestem (BB), little bluestem (LB), and switchgrass (SW) determined in August 1993, 15 months after planting, near Clay Center, NE in May 1992.

\begin{tabular}{|c|c|c|c|c|c|c|c|c|}
\hline \multirow[b]{2}{*}{ Herbicide } & \multirow[b]{2}{*}{ Rate } & \multirow{2}{*}{$\begin{array}{c}\text { Time of } \\
\text { Application }^{\mathrm{a}}\end{array}$} & \multicolumn{3}{|c|}{ Stand frequency } & \multicolumn{3}{|c|}{ Herbage mass } \\
\hline & & & BB & LB & SW & BB & LB & SW \\
\hline \multicolumn{3}{|c|}{ g ai/ha } & \multicolumn{3}{|c|}{$\%$} & \multicolumn{3}{|c|}{$-\mathrm{kg} / \mathrm{ha}$} \\
\hline Non-treated & 1 & - & 26 & 0 & 0 & 390 & 0 & 0 \\
\hline Atrazine & 2200 & PRE & 18 & 5 & 1 & 590 & 70 & 20 \\
\hline Imazapyr & 45 & PRE & 71 & 33 & 51 & 2000 & 690 & 1980 \\
\hline Imazapyr & 70 & PRE & 84 & 55 & 77 & 3580 & 1940 & 5800 \\
\hline Imazapyr & 110 & PRE & 57 & 64 & 53 & 5490 & 5050 & 7520 \\
\hline Imazethapyr & 45 & PRE & 83 & 28 & 44 & 2810 & 610 & 1920 \\
\hline Imazethapyr & 70 & PRE & 94 & 66 & 39 & 4340 & 2740 & 1300 \\
\hline Imazethapyr & 110 & PRE & 90 & 79 & 49 & 6490 & 5360 & 3200 \\
\hline Imazethapyr & 45 & POST & 90 & 13 & 5 & 1450 & 170 & 10 \\
\hline Imazethapyr & 70 & POST & 70 & 39 & 5 & 2140 & 1040 & 100 \\
\hline Imazethapyr & 110 & POST & 98 & 31 & 6 & 4470 & 1590 & 80 \\
\hline $\operatorname{LSD}(0.05)$ & & & 27 & 28 & 16 & 1550 & 1730 & 1500 \\
\hline
\end{tabular}

Response of native grasses to imazapyr at Clay Center was different than at Mead. Variation in weed pressure between research sites may explain observed differences in grass response to imazapyr. Annual grass weed pressure was much greater at Clay Center than at Mead. Increased weed abundance could have caused increased uptake and more rapid removal of imazapyr from the soil at Clay Center and decreased the amount of herbicide to which seedlings of the planted grasses were exposed.

The imidazolinone herbicides improved establishment of selected native warm-season forage grasses. Imazethapyr at 70 or $110 \mathrm{~g} / \mathrm{ha}$ PRE resulted in stands of big bluestem and little bluestem that were similar or superior to stands established where atrazine was applied. Switch-grass response to imazethapyr was not consistent at all the sites. Imazethapyr appears to be a suitable replacement for atrazine to improve big bluestem and little bluestem establishment, but may not be for switchgrass establishment. Susceptibility of seedling grasses to imazapyr could limit its use during native grass establishment. An exception was at Clay Center where imazapyr actually improved native grass establishment compared to atrazine (Table 3). Imazethapyr applied PRE usually resulted in better establishment of the grasses than where the herbicide was applied POST. Difference in efficacy between PRE and POST treatments appeared to be influenced by weed growth stage at time of application. Weeds usually were beyond the growth stage for optimum control when POST treatments were applied. 


\section{Leafy spurge-infested rangeland reclamation}

Fall-applied herbicide treatments had different effects on the various components of the vegetation on range sites measured II MAT near Ainsworth and Ansley, NE. At both study sites, big bluestem stand frequencies and herbage mass were greater where imazapyr was applied with sulfometuron than where these herbicides were applied alone (Table 4). Stand frequencies of big bluestem were 70\% where imazapyr and sulfometuron were applied together. Big bluestem, planted into plots 7 MAT with a combination of imazapyr at $560 \mathrm{~g} / \mathrm{ha}$ and sulfometuron at $100 \mathrm{~g} / \mathrm{ha}$, produced more than $1000 \mathrm{~kg} / \mathrm{ha}$ by 4 months after planting.

Indiangrass establishment was poor compared to big bluestem. Indiangrass stand frequencies were greatest at Ansley where imazapyr at 560 or $840 \mathrm{~g} / \mathrm{ha}$ had been applied alone before planting (Table 4). Indiangrass appeared to be susceptible to sulfometuron because stand frequencies were low where sulfometuron was applied either alone or with imazapyr. At Ansley, indiangrass herbage mass was greater on plots treated with imazapyr at $840 \mathrm{~g} /$ ha than the non-treated plots. At Ainsworth, indiangrass herbage mass was $\leq 100 \mathrm{~kg} / \mathrm{ha}$, regardless of herbicide treatment.

Switchgrass establishment appeared to be better at Ansley than at Ainsworth. Switchgrass stand frequencies at Ansley tended to be greatest where imazapyr was applied at $840 \mathrm{~g} / \mathrm{ha}$ or at any rate combined with sulfometuron (Table 4). There were no differences in switchgrass stand frequencies where imazapyr was applied either alone or with sulfometuron at Ainsworth. Switchgrass herbage mass at Ansley was greater where imazapyr at $840 \mathrm{~g} / \mathrm{ha}$ plus sulfometuron was applied when compared to other treatments except imazapyr at $560 \mathrm{~kg} / \mathrm{ha}$ plus sulfometuron. Switchgrass herbage mass at Ainsworth was maximized in plots treated with imazapyr at $560 \mathrm{~g} / \mathrm{ha}$.

Imazapyr at 560 and $840 \mathrm{~g} / \mathrm{ha}$ alone or imazapyr at any rate combined with sulfometuron reduced leafy spurge herbage mass II MAT (Table 4). Leafy spurge herbage mass was reduced $>60 \%$ at Ansley and $>70 \%$ at Ainsworth following treatment with imazapyr at 560 or $840 \mathrm{~g} /$ ha compared to non-treated plots. In contrast, herbage mass of leafy spurge II MAT with imazapyr at $280 \mathrm{~g} / \mathrm{ha}$ was the same as that in plots not treated with herbicide. This result is consistent with findings of Masters et al . (10). Combining imazapyr at 560 or $840 \mathrm{~g} /$ ha with sulfometuron resulted in $>90 \%$ reduction in leafy spurge herbage mass when compared to herbage mass on non-treated plots. In another study, Stougaard et al. (19) determined that imazapyr at $840 \mathrm{~g} / \mathrm{ha}$ applied with sulfometuron at $100 \mathrm{~g} /$ ha reduced leafy spurge herbage mass II MAT. Sulfometuron or glyphosate applied alone had no effect on leafy spurge II MAT.

Exotic cool-season grasses. Kentucky bluegrass and smooth bromegrass, usually were reduced by treatments that included imazapyr (Table 4). Imazapyr applied alone at 560 or $840 \mathrm{~g} /$ ha decreased cool-season grass herbage mass $>30 \%$ at both sites. Sulfometuron applied with imazapyr reduced cool-season grass herbage mass $>55 \%$ at Ansley and $>$ $70 \%$ at Ainsworth, which was greater than the herbage mass decrease measured where imazapyr was applied alone. Sulfometuron applied alone reduced coolseason grass herbage mass only at Ainsworth when compared to non-treated plots. Glyphosate did not suppress the cool-season grasses II MAT at Ainsworth or Ansley.

Page 11 of 18 
Table 4. Stand frequency and herbage mass of big bluestem (BB), indiangrass (IN), and switchgrass (SW) and herbage mass of leafy spurge (LS), cool-season grasses (COOL), other warm-season grasses (WARM), and forbs (FORB) at rangeland sites near Ainsworth and Ansley, NE that was treated with herbicides in September 1992, seeded with grasses in April 1993, and sampled in August 1993.

\begin{tabular}{|c|c|c|c|c|c|c|c|c|c|c|c|}
\hline \multirow[b]{2}{*}{$\begin{array}{l}\text { Location and } \\
\text { herbicide treatment }\end{array}$} & \multirow[b]{2}{*}{ Rate } & \multicolumn{3}{|c|}{ Stand frequency } & \multicolumn{7}{|c|}{ Herbage mass } \\
\hline & & $\mathrm{BB}$ & $\mathrm{IN}$ & SW & $\mathrm{BB}$ & IN & SW & LS & COOL & WARM & FORB \\
\hline & $\mathrm{g}$ ai/ha & 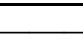 & $\%$ & 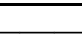 & 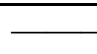 & & 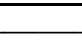 & $-\mathrm{kg} / \mathrm{ha}$ & + & 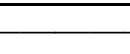 & 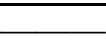 \\
\hline \multicolumn{12}{|l|}{ Ainsworth } \\
\hline Non-treated & 0 & 1 & 2 & 7 & 0 & 0 & 10 & 980 & 2870 & 200 & 150 \\
\hline Imazapyr & 280 & 21 & 20 & 23 & 30 & 30 & 40 & 710 & 2000 & 150 & 40 \\
\hline Imazapyr + sulfumeturon & $280+100$ & 74 & 10 & 28 & 500 & 10 & 110 & 190 & 860 & 340 & 0 \\
\hline Imazapyr & 560 & 42 & 32 & 36 & 150 & 60 & 290 & 300 & 1920 & 220 & 20 \\
\hline Imazapyr + sulfometuron & $560+100$ & 87 & 8 & 27 & 1070 & 30 & 90 & 50 & 430 & 130 & 10 \\
\hline Imazapyr & 840 & 24 & 24 & 31 & 120 & 100 & 110 & 60 & 1700 & 1060 & 20 \\
\hline Imazapyr + sulfometuron & $840+100$ & 85 & 5 & 32 & 660 & 10 & 100 & 30 & 230 & 20 & 0 \\
\hline Sulfometuron & 100 & 55 & 5 & 2 & 300 & 0 & 10 & 1120 & 2050 & 170 & 10 \\
\hline Glyphosate & 840 & 2 & 0 & 2 & 10 & 0 & 0 & 1210 & 2310 & 450 & 90 \\
\hline $\operatorname{LSD}(0.05)$ & & & 21 & & & 170 & - & 500 & 690 & NS & 90 \\
\hline \multicolumn{12}{|l|}{ Ansley } \\
\hline Non-treated & 0 & 0 & 0 & 1 & 10 & 10 & 20 & 580 & 1490 & 80 & 450 \\
\hline Imazapyr & 280 & 16 & 6 & 8 & 100 & 100 & 70 & 520 & 1400 & 60 & 320 \\
\hline Imazapyr + sulfometuron & $290+100$ & 77 & 3 & 68 & 890 & 10 & 350 & 230 & 630 & 340 & 60 \\
\hline Imazapyr & 560 & 54 & 40 & 43 & 380 & 310 & 310 & 220 & 770 & 60 & 390 \\
\hline Imazapyr + sulfometuron & $560+100$ & 85 & 8 & 81 & 1270 & 60 & 470 & 50 & 460 & 120 & 60 \\
\hline Imazapyr & 840 & 59 & 69 & 64 & 450 & 540 & 280 & 170 & 960 & 40 & 350 \\
\hline Imazapyr + sulfometuron & $840+100$ & 86 & 7 & 75 & 1000 & 20 & 680 & 20 & 360 & 130 & 50 \\
\hline Sulfometuron & 100 & 25 & 0 & 10 & 170 & 10 & 50 & 480 & 1300 & 270 & 90 \\
\hline Glyphosate & 840 & 3 & 0 & 4 & 0 & 10 & 10 & 590 & 1460 & 70 & 310 \\
\hline $\operatorname{LSD}(0.05)$ & & 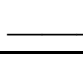 & 18 & — & 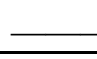 & 290 & Z & 230 & 320 & 170 & NS \\
\hline
\end{tabular}


Response of the remaining vegetation components sampled, warm-season grasses (not including planted native grasses) and forbs to various herbicide treatments was not consistent across study sites. Distribution of warm-season grasses and forbs was highly variable, and sampling technique used to determine herbage mass may not have been sensitive enough to quantify accurately these two components of the plant communities studied. The warm-season grasses tended to be greater where sulfometuron was a component of the herbicide treatment, but the forb component of the community at Ainsworth was suppressed by treatment with imazapyr and/or sulfometuron (Table 4).

Optimum treatment for establishment of big bluestem and switchgrass was imazapyr at $560 \mathrm{~g} /$ ha applied with sulfometuron at $100 \mathrm{~g} / \mathrm{ha}$ in the fall. This treatment suppressed the resident leafy spurge and less desirable coolseason grasses at both sites, which enabled excellent establishment of big bluestem at both sites and switchgrass at Ansley. Rainfall distribution and amount also may have contributed to successful establishment of big bluestem and switchgrass. Cumulative precipitation during the period April through July 1993 was 59 and 48\% greater than the long-term average at Ansley and Ainsworth, respectively.

Comparison of relative species composition of the herbicide-treated and non-treated plots planted to big bluestem further illustrate the effects of herbicide treatments and reseeding. At Ainsworth, leafy spurge and coolseason grasses comprised 23 and 68\%, respectively, of the total herbage mass on the non-treated plots and only 3 and $24 \%$ of the herbage mass on plots treated with imazapyr and sulfometuron (Table 4). At Ansley, leafy spurge and cool-season grasses comprised 22 and $56 \%$, respectively, of the total herbage mass on the non-treated plots and only 2 and $18 \%$ of the total herbage mass on plots treated with imazapyr at $560 \mathrm{~g} /$ ha plus sulfometuron. Big bluestem was $<1 \%(10$ $\mathrm{kg} / \mathrm{ha}$ ) of the total herbage mass where no herbicide was applied, but comprised $51 \%$ $(1270 \mathrm{~kg} / \mathrm{ha})$ of the herbage mass where imazapyr at $560 \mathrm{~g} /$ ha plus sulfometuron were applied. This shift in composition is desirable because it reflects a reduction in leafy spurge and less desirable cool-season grasses and an increase in big bluestem, a highly productive native tallgrass. The contribution of big bluestem, and other planted native grasses, should increase with time as native tallgrass stands mature.

To summarize the restoration strategy developed consisted of three phases. First, herbicides were applied in the fall to suppress existing vegetation and reduce interference with warm-season tallgrasses planted the following spring. Second, the herbicide- treated areas were burned in the spring to suppress emerging plants and to remove standing plant residue that would otherwise interfere with placement of tallgrass seed in the soil. Third, warm-season grasses were planted to improve forage species composition and production, increase native species diversity, and more effectively interfere with leafy spurge than the existing vegetation.

\section{Forb establishment}

AC 263,222 provided better control of the dominant weed, smooth crabgrass [Digitaria ischaeum (Schreb. ex Schweig.) Schreb. ex Muhl. \# DIGIS], than did imazethapyr I MAT (Table 5). Emergence of Illinois bundleflower and trailing crownvetch seedlings was greater in AC 263,222- and imazethapyr-treated plots than in plots not treated with herbicide I MAT (Table 5). AC 263,222 reduced Illinois bundleflower and purple prairie- 
clover emergence as compared to imazethapyr. The adverse impact of AC 263,222 on emergence of certain forbs I MAT became less apparent as the growing season progressed.

Table 5. Smooth crabgrass control 1 MAT and emergence of blackeyed-susan (BS), trailing crownvetch (CV), Illinois bundleflower (IB), purple prairieclover (PC), upright prairie coneflower (UC), seedlings 1 MAT near Mead, NE in June 1994.

\begin{tabular}{|c|c|c|c|c|c|c|c|}
\hline \multirow[b]{2}{*}{ Herbicide } & \multirow[b]{2}{*}{ Rate } & \multirow[b]{2}{*}{ Control } & \multicolumn{5}{|c|}{ Emergence by species ${ }^{\mathrm{a}}$} \\
\hline & & & $\mathrm{BS}$ & $\mathrm{CV}$ & IB & $\mathrm{PC}$ & $\mathrm{UC}$ \\
\hline & $\mathrm{g}$ ai/ha & $\%$ & 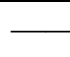 & - & $-\%$ & 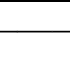 & 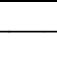 \\
\hline Non-treated & 0 & 0 & 1 & 1 & 25 & 10 & 0 \\
\hline AC 263,222 & 70 & 96 & 4 & 59 & 57 & 13 & 1 \\
\hline Imazethapyr & 70 & 67 & 16 & 64 & 71 & 34 & 4 \\
\hline $\operatorname{LSD}(0.05)$ & & 3 & 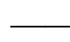 & 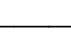 & $-12-$ & & \\
\hline
\end{tabular}

${ }^{\mathrm{a}} 0 \%=$ no emergence; $100 \%=$ complete emergence.

Irrigation resulted in greater foliar cover of all forbs treated with AC 263,222 except Illinois bundleflower and all forbs treated with imazethapyr except purple prairieclover (Table 6). By 2.5 MAT, Illinois bundleflower, purple prairieclover, and trailing crownvetch foliar cover was greater in plots treated with herbicide than in plots not treated with herbicide, regardless of irrigation regime. Foliar cover of blackeyed-susan and upright prairie coneflower was greatest in irrigated plots treated with either herbicide. Within irrigation treatment, only purple prairieclover response varied between the two herbicides. Purple prairieclover foliar cover was actually greater in irrigated plots treated with AC 263,222 than in imazethapyr-treated irrigated plots.

Table 6. Foliar cover of non-irrigated (NI) and irrigated (I) blackeyed-susan (BS), trailing crownvetch (CV), Illinois bundleflower (IB), purple prairie clover (PC), and upright coneflower (UC) 2.5 MAT near Mead, NE in June 1994.

\begin{tabular}{|c|c|c|c|c|c|c|c|}
\hline \multirow[b]{2}{*}{ Herbicide } & \multirow[b]{2}{*}{ Rate } & \multirow[b]{2}{*}{ Irrigation } & \multicolumn{5}{|c|}{ Canopy cover by species ${ }^{\mathrm{a}}$} \\
\hline & & & $\mathrm{BS}$ & $\mathrm{CV}$ & IB & $\mathrm{PC}$ & $\overline{\mathrm{UC}}$ \\
\hline & g ai/ha & $\%$ & 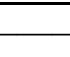 & 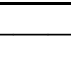 & $\%$ & & \\
\hline Non-treated & 0 & NI & 0 & 0 & 8 & 0 & 4 \\
\hline Non-treated & 0 & I & 0 & 0 & 10 & 0 & 0 \\
\hline AC 263,222 & 70 & NI & 5 & 70 & 85 & 25 & 5 \\
\hline AC 263,222 & 70 & I & 78 & 95 & 88 & 55 & 36 \\
\hline Imazethapyr & 70 & NI & 15 & 56 & 71 & 24 & 4 \\
\hline Imazethapyr & 70 & I & 73 & 93 & 91 & 33 & 29 \\
\hline LSD $(0.05)$ & & 3 & 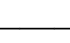 & 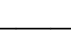 & 17 & & \\
\hline
\end{tabular}

${ }^{\mathrm{a}} 0 \%=$ no canopy; $100 \%=$ complete canopy closure. 
AC 263,222 and imazethapyr improved establishment of most forbs evaluated in this study. These forbs have value as either low maintenance ornamentals, complementary forages, or components of grass/forb seed mixtures planted to stabilize erodible sites, e.g., roadsides and marginal cropland. AC 263,222 and imazethapyr are useful tools that can reduce weed interference during forb establishment.

\section{Management implications}

The imidazolinone herbicides have the potential to expedite revegetation of native grasslands in the Great Plains where warm-season grasses have dominated historically. Rapid grassland revegetation is highly desirable because it enables three important land management goals to be achieved. First, rapid establishment of perennial species on highly erodible or marginal cropland is necessary to reduce soil erosion and degradation of soil and water quality.

Second, livestock enterprises that rely on grasslands as a primary forage resource benefit from increased quality and quantity of warm-season native forages after revegetation. In the central and northern Great Plains there is currently a lack of forages during the summer and an abundance of cool-season forages and crop residues available during the spring, fall, and winter. Grassland revegetation provides an opportunity to balance seasonal forage availability by reintroducing native warm-season grasses and forbs that provide high quality forage in the summer.

Third, reclaiming degraded grasslands and converting highly erodible cropland back to grassland increases native species diversity. Diverse plant communities are potentially more resilient to disturbance. More diverse grasslands will be better able to sustain stable ecosystem processes over a range of disturbances, e.g., grazing and periodic droughts, and return to a desirable steady state once disturbances moderate. Overall, the imidazolinone herbicides provide powerful tools that enable producers to exploit the benefits of native perennial species and move toward more sustainable and resource-use-efficient agronomic production systems.

\section{Future research}

Research is needed to develop site-specific management strategies to restore the great variety of marginal cropland and degraded grassland sites in the Great Plains. Investigation of interactions among various species in restored grasslands is needed to develop the most effective strategies to sustain the dominance of desirable native species. Techniques should be developed to enhance establishment of native grasses and forbs that are less common to increase species diversity within grassland communities.

Grazing management schemes need to be identified that will maintain restored grasslands. Grazing should be a critical component of strategies that lead to grassland restoration for two reasons. First, livestock producers will embrace and adopt practices that contribute to grassland restoration when they realize the tangible economic value of improving carrying capacity with native forages. This is especially important in the Great Plains, because most marginal cropland and degraded grassland are privately owned and the economic burden of restoration will be largely borne by the producer. Second, graz- 
ing by native ungulates was one of the primary forces responsible for formation and maintenance of grasslands. Therefore, proper grazing management is needed to maintain diverse grassland communities.

Rapid establishment of native, warm-season, perennial grasses and forbs on cropland and degraded grassland in the central Great Plains can be achieved with imidazolinone herbicides. Once established, it is essential to apply management strategies that shift the competitive advantage to native species and away from invasive exotic species. Conceptually, the sequential application of herbicides, reintroduction of competitive native plants, fire, grazing, and classical biological control could provide long-term suppression of exotic species and increase native plant diversity.

Sequential application of complementary weed management practices could overcome the limitations inherent with any single technology applied alone and increase the efficacy and economic feasibility of grassland restoration. Scifres (15) describes advantages of sequential treatments relevant to brush management in Texas. These benefits include increasing the spectrum of woody species suppressed and the effectiveness and longevity of expensive treatments.

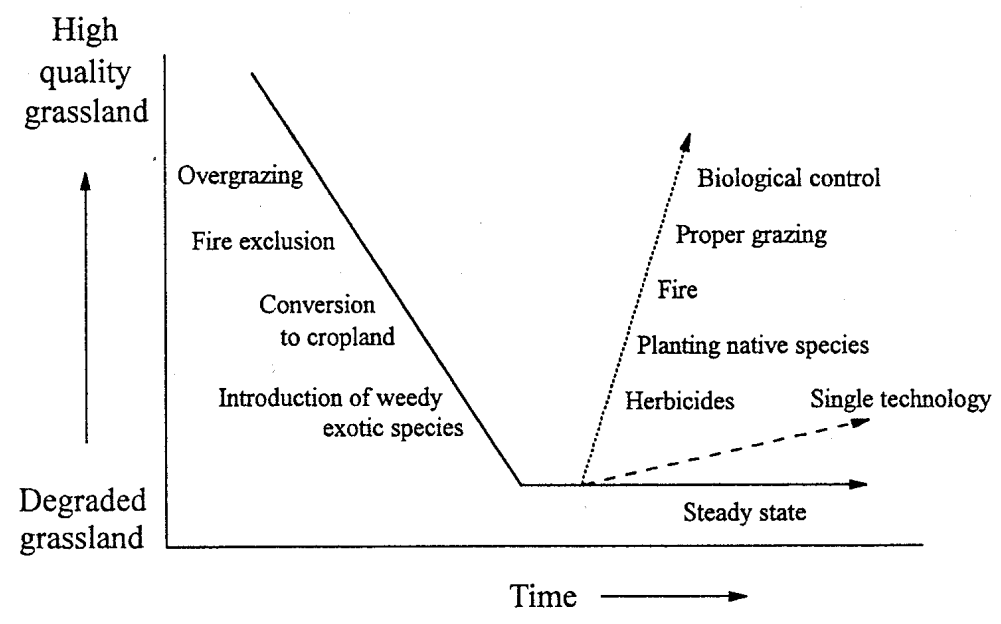

Figure 1. Proposed successional process model for Great Plains grasslands. Initial retrogression results from combined effects of several factors including overgrazing, exclusion of fire, conversion to cropland, and introduction of invasive exotic species. Retrogression leads to a steady state condition of reduced native species diversity and increased encroachment of invasive exotic species. Opportunities to manage succession to increase native species diversity and productivity are determined by use of weed management technologies (i.e., herbicides, planting native species, fire, proper grazing, biological control) in appropriate combinations and sequences. Reliance on a single technology will likely result in a slow rate of grassland recovery. Sequential application of different technologies that are complementary accelerates succession towards a high quality native species-rich grassland community. 
Weed management technologies applied in appropriate combinations and sequences in the Great Plains could accelerate movement along a successional trajectory away from a steady state community dominated by a few exotic species and unpalatable native species toward grasslands that are rich with native species (Figure 1). Our goal is to develop economical integrated weed management strategies that will enable land stewards to reverse grassland deterioration by manipulating successional processes on degraded grasslands and marginal cropland. Grassland restoration objectives that can be achieved through proper successional management include increasing native species diversity, increasing carrying capacity, improving soil and water quality, and decreasing exotic species.

\section{Acknowledgments}

The authors thank Kevin Grams, Leonard Wit, Mack Thompson, Ken Carlson, Ginger Bauers, and Brenda Younkin for their assistance and American Cyanamid, the Nebraska Leafy Spurge Working Task Force, the University of Nebraska Foundation, Arthur Sampson Range and Pasture Management Endowment Fund, and the Nebraska Turfgrass Foundation for partial support.

\section{Literature cited}

1. Archer, S. and F. E. Smeins. 1991. Ecosystem-level process. p. 109-140 in R. K. Heitschmidt and J. W. Stuth, eds. Grazing Management: An Ecological Perspective. Timber Press, Portland, OR. 259 p.

2. Barbour, M. G., J. H. Burk, and W. D. Pitts. 1987. Terrestrial Plant Ecology. 2nd ed. Benjamin/Cummings, Menlo Park, CA. 634 p.

3. Betz, R. F. 1986. One decade of research in prairie restoration at the Fermi National Accelerator Laboratory (Fermilab), Batavia, Illinois. p. 179-185 in G. K. Clambey and R. H. Pemble, eds. Proc. Ninth North American Prairie Conf., Moorhead, MN.

4. Bovey, R. D 1987. Weed control problems, approaches, and opportunities in rangeland. Rev. Weed Sci. 3:57-92.

5. Goldsmith, F. B. and C. M. Harrison. 1976. Description and analysis of vegetation. p. 85-155 in S. B. Chapman, ed. Methods in Plant Ecology. Halstead Press, New York.

6. Jordan, W. R., R. L. Peters, and E. B. Allen. 1988. Ecological restoration as a strategy for conserving biological diversity. Environ. Manage. 12:55-72.

7. Kuzila, M. 1989. Soil associations and series. p. 58-66 in A. Bleed and C. Flowerday, eds. An Atlas of the Sand Hills. Resource Atlas No. 5. Univ. Nebraska Press, Lincoln.

8. Laycock, W. A., C. H. Herbel, and R. F. Barnes. 1982. SEA-AR range research in Colorado, Wyoming, Nebraska, and Kansas. p. GPC-1-33 in Range research: An Assessment of Current Problems and a Strategy for the Future. USDA-SEA Admin. Rep.

9. Masters, R. A. 1995. Establishment of big bluestem and sand bluestem cultivars with metolachlor and atrazine. Agron. J. 87:592-596,

10. Masters, R. A., R. N. Stougaard, and S. J. Nissen. 1994. Leafy spurge (Euphorbia esula) control with fall-applied imazapyr, imazaquin, and imazethapyr. Weed Technol. 8:58-63.

11. Masters, R. A., K. P. Vogel, and R. B. Mitchell. 1992. Response of central plains tallgrass prairie to fire, fertilizer, and atrazine. J. Range Manage. 45:291-295. 
12. Mlot, C. 1990. Restoring the prairie. BioScience 40:804-809.

13. Ott, L. 1977. An Introduction to Statistical Methods and Data Analysis. Duxbury Press, Belmont, CA. $730 \mathrm{p}$.

14. Schramm, P. 1992. Prairie restoration: A twenty-five year perspective on establishment and management. p. 169-177 in D. D. Smith and C. A. Jacobs, eds. Proc. 12th North American Prairie Conf. Cedar Falls, IA.

15. Scifres, C. J. 1987. Decision-analysis approach to brush management planning: Ramifications for integrated range resources management. J. Range Manage. 40:482-490.

16. Shirley, S. 1994. Restoring the Tallgrass Prairie. Univ. Iowa Press, Iowa City. 330 p.

17. Smith, D. D. 1992. Tallgrass prairie settlement: Prelude to demise of the tallgrass ecosystem. p. 195199 in D. D. Smith and C. A. Jacobs. eds. Proc. 12th North American Prairie Conf. Cedar Falls, IA.

18. Statistical Analysis System Institute, Inc. 1985. SAS User's Guide: Statistics. Version 5 ed. SAS Inst., Inc. Cary, NC. 956 p.

19. Stougaard, R. N., R. A. Masters, and S. J. Nissen. 1994. Leafy spurge (Euphorbia esula) control with imidazolinone and sulfonylurea herbicides. Weed Technol. 8:494-498.

20. USDA-NRCS. 1994. National natural resources inventory database. Misc. Pubi.

21. Vogel, K. P 1987. Seeding rates for establishing big bluestem and switchgrass with preemergence atrazine applications. Agron. J. 79:509-512.

22. Weaver, J. E. and T. J. Fitzpatrick. 1934. The prairie. Ecol. Monogr. 4:109-295. 